\title{
Model Practice Of Drafting The Code Of Ethics Of Politicians And Political Parties In Indonesia
}

\author{
Muryanto Amin
}

\author{
Department of Political Science, Faculty of Social and Political Science, \\ University of North Sumatra. Medan, Indonesia \\ muryantoamin@usu.ac.id
}

\begin{abstract}
The code of ethics is necessary for politicians and political parties in Indonesia which is currently being consolidated democracy for the people's welfare. The code of conduct is drawn up as a standard of behavior to reduce reality to rampant crime and corruption, bribery and abuse of power involving politicians of the Centre in almost all branches of power, Executive, legislative, and judicial. The research question to be answered is how to model the practice of drafting ethics of politicians and political parties in Indonesia? Research results explain that enforcement of the code of conduct is very important for politicians with models of different options through the judiciary. There's the judgement that justice is done, but the result was announced to the public. Others argued that justice be done openly as a form of accountability to the public is widely and so that's not the case processes diverge. Judicial ethics know no immunity or immunity to a person who is referred to as politicians. The given sanctions need to be concrete or obvious as a form of sanction that has a deterrent effect for politicians and political parties. Enforcement of ethics also provide opportunities for rehabilitation of the honor and dignity of politicians when in the trial in question was not proven misconduct or breach of ethics charged.
\end{abstract}

Keywords: ethics, politicians, and political parties

\section{INTRODUCTION}

Every profession, including work as a politician in a broader sense, basically is required to have a code of conduct as standards of conduct so that the dignity and the profession's honor as a politician can be guarded, protected, and enforced. Similarly, political parties, as well as a container of selfactualization for the politicians, political parties require a framework of conduct or specific code of ethics as a reference in implementing strategic position as one of the most important pillars of the democratic system. As a body of public law, political parties do not only need to be professionally managed, open, and democratic, but also expected really oriented to the public interest. On the other hand, politicians of every political party expected to have minimum standards of conduct, so that deserve the political mandate when they became representatives in representative institutions, such as Parliament, provincial and REGIONAL district/city, or when assuming public office more, both at national and regional level.

Therefore, at the same time Institutionalization and enforcing a code of conduct for political parties and politicians are requirements, not only in order to safeguard and protect the dignity, honor and dignity, political parties are institutions and politicians individually, but also in efforts to uphold the standards of behavior that qualify the propriety in a democratic system. As the pillars of the democratic system, any political parties and politicians who joined in it is claimed has a minimum standard of behavior to expect could be the guidance at the same time the Foundation works of the democracy and governance are healthy as well as the interests of the people-oriented, the nation and the State.

In addition to be the needs of the political parties and politicians, standards of conduct in the form of a code of ethics is also required by the public and constituents as a reference in assessing the behavior of 
political parties and politicians in carrying out their role as "a bridge" between the people and the Government. Furthermore, public and constituent eligible candidates or public officials who are not only competent and professional, but also has integrity and responsible. In short, public or constituents as the owner of sovereignty in politics, has the right to be represented and led by politicians who meet certain ethical standards, so that the ideals of popular sovereignty, justice, and prosperity as mandated by the 1945 NRI Preamble can be realized.

As a relatively new country practicing back democratic system - after a long period of authoritarian system for nearly four decades (1959-1998) under the Guided Democracy and democracy of Pancasila (the new order) - political parties and politicians in Indonesia clearly need a code of conduct as the behavior standard. The need was increasingly urgent if it's connected with the reality of the rampant crime of bribery and corruption, as well as abuse of power involving politicians of the Centre in almost all branches of power, Executive, legislative, and judicial. Since 1999 when the country was increasingly democratic and increasingly free elections, democratic, and even outright, a variety of criminal acts of bribery and corruption by public officials that comes from the political party apparently tended to increase as well. Recent development at this time, the age of the politicians who caught a case of bribery and corruption more young and come from almost all political parties, including the Centre of religious and political parties also based that internally has enacted a code of ethics for their cadre.

In terms of coverage, the crime of bribery and corruption does not only involve the regional head/Deputy Head of a region in the province and regency/city, but also a Minister of State who comes from a political party. In the branch of legislative power, corruption and bribery cases involving legislative, so that not a few of them being "patient" institutions of the Corruption Eradication Commission (KPK). Meanwhile in the judicial branch of power, bribery and corruption cases involving the former Chairman of the Constitutional Court, Akil Mochtar, who in fact is behind it as politicians, is an example of the most phenomenal.

The reality expressed above is obviously very worrying. On the one hand of the Centre which has a strategic position and functions as a bridge between the people and the Government, it is hoped could be the solution for the problems of the nation and the State. But on the other political parties in reality was thus still be a "burden" for our nation. The gap between the expectations and the reality of the political parties and politicians here's what necessitates the urgency of institutionalization and the enforcement of the code of conduct as standards of conduct for political parties and politicians. The question to be answered in this research is how to model the practice of drafting ethics of politicians and political parties in Indonesia?

\section{RESEARCH METHODS}

This research used the qualitative approach with case studies as a research strategy. 1This approach is directed at setting and the individual holistically or intact. Data obtained either in the form of a written document or the results of the in-depth interviews and observations will be analyzed using qualitative analysis technique of typology. Avoiding or minimizing the possibility of bias, the author is trying to match the results of the interview between one resource person other then from the found documents about the interconnectedness of the implementation of the code of ethics of politicians and political parties with a case violations of ethics.

\subsection{Perspective Theory}

The political party is the main pillar of democracy. As a pillar of democracy, the

1Robert K. Yin. 2009.Case Study Research, Design and Methods. Fourth Edition. Thousand Oaks: Sage Publications. 
existence of political parties is crucial and fundamental intention life can affect many people. Political parties in certain extent be the only public organization which became a source of replenishment of strategic offices, both at national and local levels. For a country of democracy, a political party is an organization that was created to be able to articulate the interests and aspirations of the community on an ongoing basis. Maor defines a political party as an organization of groups that propose candidates for political office to selected by the people so that they can control and influence the actions of the Government. 2Political party that actually determine the democracy, "political parties created democracy". Political party is a very important pillar for reinforced institutionalization degree (the degree of institutionalization) in any democratic political system "of modern democracy is unthinkable save in terms of the parties".3

However, many also view critical and even skeptical of political parties, of which States that political parties that are actually nothing more than a political vehicle for a group of the ruling elite or intend to satisfy ' his power Lust ' own. Political parties only serves as an instrument for a handful of people who happened to get lucky to win people's votes are easily fooled, to force the enactment of certain public policies 'at the expense of the general will 'or the public interest.4

Each State democracy, the position and the role of the institutions of the State must be the same strong and mutually controlling in a relationship of "checks and balances". But if the institutions are not functioning

2Moshe Maor, Political Parties \& Party Systems: Comparative Approaches \& the British Experience, (London and New York: Routledge, 1997), hlm. 15. See also Ichlasul Amal, ed., Teori-Teori Mutakhir Partai Politik, (Yogyakarta: TWC, 1996), hlm. 1. 3E.E. Schattschneider. 1942. Party Government. New York: Holt. Rinehart and Winston, pg. 42 4Explanation the idea about public will seJean Jacques Rousseau. 1762. The Social Contract Or Principles of Political Right. Virgi:

FoederisæquasDicamusleges properly, its performance was ineffective, or the weak authority of the Agency in the exercise of their respective functions, then often happens is a political party that does not behave democratically controlled and who will control the whole process of organizing functions of Government.

Therefore, the party system is a good system works attempt to determine based on the principle of "checks and balances" in the broad sense. On the contrary, effective institutional functions works the country according the principle of "checks and balances" on the basis of the Constitution also greatly determine the quality of the party system and the mechanisms of democracy developed in a country. All this of course is closely related to the dynamics of the growth of the tradition and culture of free thinking in the life of society. The tradition of thought or freedom of thought that in turn affect the growth and development of the principles of freedom of Association and Assembly in the dynamics of the democratic life of the community is concerned.

The political party is one of the forms of institutional community to embody the expression in the form of ideas, thoughts, views, and beliefs in a democratic atmosphere. In addition to political parties, other incarnated forms of expression also in the form of freedom of the press, freedom of Assembly, freedom of Assembly or through a non-organizations of political parties such as non-governmental organizations (NGOs), community organizations (Cbos), non government organizations (NGO's), and others.

However, in relation to the activities of the State, the role of political parties as a medium and means it must be very prominent. In addition to other institutional like the free press and the role of enlightened middle-class, and so on, the role of political parties can be said to be very decisive in the dynamics of State activities. Political Party however also very instrumental in the dynamic process of the struggle of the values and interests (values and interests) of the constituents it represents to determine policy 
within the context of the activities of the State. The political party that acted as an intermediary in the decision-making processes of State, connecting citizens with the institutions of the Union. According to Robert Michels in his book, "Political Parties, A Sociological Study of the Oligarchical Tendencies of Modern Democracy", ".. .the organization is the only economic or political means to shape the collective willpower".5

The opportunity to succeed in every struggle interests very much depends on the level of unity in the organization. The level of community that are organized in an orderly and organise in the implementation of joint struggle between people who have the same interests who are members of the organization concerned. Therefore, it can be said that freedom of Association was a prerequisites are mandatory and essential for any political struggle. On that basis, it must be recognized that the role of the party organizations is very important in the framework of the dynamics of the institutionalization of democracy. Through the Organization, the struggle of common interest into a powerful position in the face of the opponent or rival party, because the forces are small and fragmented can be consolidated in a single front.

The process of institutionalization of democracy it was very substantially determined by the institutionalization of political parties organization as part and parcel of the democratic system itself as described Yves Keep and Andrew Knapp, "A democratic system without political parties or with a single party is impossible or at any rate hard to imagine".6 A political system with only one political party, it is difficult to imagine to be called democratic, especially if without any political party at all.

5Robert Michels. 1984. Partai Politik:

Kecenderungan Oligarkis dalam Birokrasi. Jakarta: Penerbit Rajawali. pg.23

6Yves Meny and Andrew Knapp. 1988.

Government and Politics in Western Europe:

Britain, France, Italy, Germany. Third Edition.

Oxford University Press. pg. 86
The level or degree of institutionalization of political parties in the democratic system itself, according to Yves Keep and Andrew Knapp, depends on three parameters, namely (i) "its age", (ii) "the depersonalization of the organization", and (iii) "organizational finding"7 Any normal organization grow and develop naturally according to the stages of its own time. The older the age, the ideas and the values espoused in the organization increasingly institutionalized (institutionalized) become a tradition in the organization.

The organization that developed the more work tend to also experience the process of "depersonalisasi". People in opposing and equally aware of the concerned organization and treat as an institution and not mixes it with the question of personal or private individuals who happen to be its administrator. Many organizations, although old, but a tradition that its administrator's personal affairs are totally separated from the organizational Affairs is not built. This means that the degree of institutionalization of the Organization as an institution, is still not strong, or more specifically has not been institutionalized as a strong organization.

If this is connected with the fact that happened in Indonesia, many once viable organization management is still very "personalized". Large organizations in the field of religion, such as the Nahdhatul Ulama, Muhammadiyah, and others with varying degrees, still showing a strong personalization symptoms or even very strong. Organizations in the field of youth, in the social field, and even in the field of education, an awful lot of that is still 'personalized', though different in degree. In fact, because of the nature of the 'personalized' of the organization in question, many of whom were soon disbanded shortly after its leader passes away.

The symptoms of "personalization" is also seen as an organization have difficulty in doing succession or succession. Monica and Jean Charlot calls it, "Until a party (or any

7Ibid.pg. 7 
association) has surmounted the crisis of finding a successor to its founder, until it has drawn up rules of succession that are legitimate in the eyes of its members, its ' institutionalization ' will remain precarious".8 as long as an organization has not been able to overcome the crisis in the turn of his leadership, and have not managed to put the basic settings that can be recognized and trusted by its members, then during this time the organization is still problematic institutionalization and yet can be said to be strong. Especially if it pertains to the changing of the leader who is the founder of the meritorious for the organization concerned, often arising difficulties to perform the turn the orderly and peaceful. However, the degree of institutionalization of the Organization in question depends on how the question of turnover that can be done in the "impersonal" and "depersoanlized".

If we use the parameter "personalization" is to assess the Organization of civic and political parties in our country today, certainly an awful lot of organization with different degrees can be said not all work in "depersonalized". Consider how the parties like Golkar (GOLKAR), the national mandate party (PAN), the Indonesian Democratic Party of struggle (PDI-P), the National Awakening Party (PKB), the United Development Party (PPP), Crescent Star Party (PBB), and so on. Some were accompanied by the split, some are not yet completely succeeded in holding the forum Congress, the National Congress or Congress.

In addition to the two parameters above, the degree of institutionalization of the organization can also be seen in terms of "organizational finding". The question of a very noteworthy is the ability of civic organizations or political parties concerned managed to organise themselves as an instrument for mobilizing the support of its

8 Monica and Jean Charlot, 'Les Groupes Politiquesdansleur Environement' in J. Leca and M. Grawitz (eds.), Traite de Science Politique, iii (Paris: PUF, 1985), 437; in Ibid.. pg. 89. constituents. Every democratic system with many political parties, the diverse aspirations and political interests that are competed in the community requires the right of distribution through the institutionalization of political parties. The larger the support that the aspiration can be mobilized and distributed by a political party, the greater the potential political parties also were to have been called institutionalized.

To guarantee their ability to mobilize and channel the aspirations that constituents, organizational structure of the concerned political parties must be organized in such a way, so that the range of interests in society be accommodated and accommodated as wide as possible. Therefore, the internal structure of political parties is important to organized appropriately. The one hand, should correspond to the need to mobilize support and channeling the aspirations of our constituents. The other, the organizational structure of political parties must also be adapted to the format of the idealized government organizations according to the vision of the political parties who requested to constituents to provide their support. Getting fit in the internal structure of the party organization to the needs, the higher the degree of institutionalization of the organization concerned.

Practice in Indonesia, political parties not merely organizational groups, but has been established by legislation as a body of public law (public institution). The political party as a body of public law has a number of consequences, among other things, these organizations cannot be owned by individuals or private, but have become an organization that is open, is bound by the norms of public interest, and other propriety principles that apply to a society. Other consequences, political parties as public legal entities also have the moral responsibility in managing the political life and State as well as to realize a better democracy. Implications for the governance of a political party is not detached at all with public ethics. The application of a public ethics has become an inevitability for 
the management of a political party in Indonesia.

At least there is some relationship between the code and the Organization of the party. First, relationship code of ethics with the Organization of the party reflected on the management of the party. Party management deals with how the party running the Government and how the party led or managed party administrators as well as how it relates to the Constitution, the applicable rules of procedure and behavior problems that apply as the norm in society. Governance of the party concerned among other things with the question of how the party organization coordinating the internal interests of the factions, how elements are arranged, and how the integrity of the sublimation and the incorporation of the various interests can be controlled.

Second, the management of a political party cannot be released from the cadre recruitment and recruitment policies are outlined and practiced by political parties. A political recruitment process essentially depends on how political parties to select candidates of party members. The process of recruitment and cadre recruitment may be short-term, and long-term, depending on the interests of political parties. Short term e.g. with regard to the process of nomination of members of the legislature, and charging the Office of prefect (Governor, Mayor) or charging-the charging other political office. This recruitment policy will determine the quality at the same time the integrity of cadres of political parties and politicians.

Third, relationship code of ethics with the Organization and leadership of the party very closely. Location of conjunction for example can be seen on who deserves to be the leader of the party? Behavior-the behavior of what should and should not be done by cadres, the administrators and the party leadership? What have been the cornerstone of governance in running an organization that does not conflict with public interests and ethics? How is the sustainability of the organizations of the party, it is concerned with the origin of the cadres of the party and who is filling and mastering

\section{RESEARCH RESULTS}

Enforcement of ethics is one of the fundamental instrument in maintaining the honor and dignity (dignity) a profession and/or organization. Enforcement of ethics governing how ethics rules (rule of ethics) supervised and enforced. Who is overseeing and enforcing the rule of ethics? The experience of many countries that embraced democracy, there is a kind of Court of ethics (court of ethics) as applicable to violations of positive law (rule of law).9 The practice is known in Indonesia, some of the agencies that enforce ethics such as the Court of honor Council (MKD) which serves to uphold the rules of conduct for members of the House of representatives (DPR), the Court of honour, the Honour of the party.10

The enforcement of the code of conduct in the election organizers known Honorary Board Election Organizers (DKPP) which was tasked to be the judicial conduct for election organizers.11 While some professional organizations, such as the journalist profession (journalism), medicine, lawyers, and researchers also have judicial ethics practised by different names, but the principle is the same. From the experience of some other countries, ethical rules require the procedure to resolve the issue that comes up. Generally the trial proceedings of conduct take place in closed, independent, and in cases that occurred in US, investigating

\footnotetext{
9 Zulfikri Suleman, "Mahkamah Etik Penyelenggara Negara di Negara Demokrasi," dalam Jurnal Etika \& Pemilu, edisi 1, Mei 2015: 14 10 Peraturan Dewan Perwakilan Rakyat Republik Indonesia Nomor 1 Tahun 2015 tentang Kode Etik Dewan Perwakilan Rakyat Republik Indonesia.

11Peraturan Dewan Kehormatan Penyelengara Pemilihan Umum Republik Indonesia Nomor 1 Tahun 2013 tentang Pedoman Beracara Kode Etik Penyelenggara Pemilihan Umum.
} 
violations of ethics based on the procedure of criminal investigation.12

Judicial conduct was necessary because of a number of reasons. First, in a democratic system, surveillance against the behavior for politicians who have important positions in a democracy is a conditio sine qua non in the life of nation and State.

Therefore the supervision in order to give sanction to be one of the options. Second, politicians is a profession that is important for a country life in democracies. Politicians such as those occupying public office, Executive Board of the party, members of Parliament, and politicians are held in the Executive Branch, has the authority to exercise power and take a policy that affects people's lives. Principle of the relationship between power and ethics, an expression of Lord Acton that power tends to be misused and abused certainly absolute power (power tends to corrupt, absolute power corrupt absolutely) has been proven in many cases in the history of the Organization of the Government. Hence needed an agency that could keep an eye on his behavior.

Third, politicians do not work in the vacuum of space (empty), but are on a public space or the norms of propriety in society. Rules and norms are in fact is the internalization of the values that idealized as goodness, Excellency and glory are dealing with bad grades, not noble and not noble. Norms of what could be, what is required and what is forbidden is in fact already known by the society from time to time. Therefore, there are values of propriety that needs to be maintained and become part of integrity as a politician.

Fourth, in order to avoid abuse of power, abuse of power, supervision against the behavior of politicians becomes an inevitability. Control and surveillance against power in the democratic system was intended to power holders have responsibility and accountability toward the position that he will hold. In addition to the reasons above,

12National Democratic Institute for International Affairs, Legislative Research Series Paper \#4, pg. 6. the judicial enforcement of ethics needs to be done by an agency that is independent, autonomous and imparsial. Proposed that the agencies that enforce ethics shaped Court of ethics which are ad hoc. Why The Court of Ethics? The shape was chosen because of ethics enforcement process should be done outside of the internal mechanism of the political parties. As we know, the experience so far indicates that the internal mechanism of the party in enforcing discipline and violations, both violations of ethics violations or outside tends to be closed, not transparent, intervened by the stronger party, unjust, and terms with political interests.

The Court are ad hoc, because this Court will only work once there is a case of ethics complaints relating to violations of the code of ethics of politicians and political parties. The Court was created by the State, if any, complaints from some agencies/institutions and/or individuals who proposed the necessity of judicial ethics. Why the State? In the principles of democracy and the modern State, the State is the highest representation of political and State for life, as an institution which represents the public interest and/or the interests of the people above the interests of groups and classes. The implementation, as a representation of the country, the President as head of State can form a Court of ethics needs to be established.

Enforcement of ethics also deals with the judiciary has the right to give the sanctions. In that regard, the trial run its shape must be fair, free of intervention (independent), and open. The judiciary should be open because the issue of ethics for politicians and political parties is not solely related to the rights and privacy of individuals, but of politicians is a profession that are public and represent the public. Therefore the process needs to be open as part of the functional responsibilities of the ethics (functional ethics) must be opened and known by the public and are not covered by reason of privacy or individual Affairs.

The results of the interviews and FGD is done, there is mention of a speaker different 
options from a number of parties. There's the judge that justice is done, but the result was announced to the public. Others argued that justice be done openly as a form of accountability to the public is widely and so that's not the case processes diverge.

Judicial ethics know no immunity, in the sense of violation of ethics only applies to cadres, party members, and leadership (Superintendent terrace) are limited. Judicial conduct apply to a person who is referred to as politicians, either as party cadres, party Executive Board, the members of the legislature, the regional head of the prospective spouses, would-be President and Vice President as well as the public officials who represent the party in the institution of the State.

The sanctions provided not merely a sanction in the form of praise or scolding, but sanctions provided in Ethics Enforcement Politicians need to be concrete or obvious as a form of sanction that has a deterrent effect for politicians and political parties. Instead, enforcement of ethics also provide opportunities for rehabilitation of the honor and dignity of politicians when in the trial in question was not proven misconduct or breach of ethics charged.

\section{COVER}

Code of ethics of politicians and political parties has been created to be the handle for politicians and political parties in the exercise of its functions and role in the system of democracy. Some countries that established democracy system also has a code of conduct for politicians and political parties. The difference is, there are countries that make the code of conduct and code of behavior separately, others incorporate them in one script. Another difference is the flashy country in applying sanctions for infringement of the code of conduct and code of behavior using agencies that are outside the party, permanent and tight, there are also countries that rely solely on internal party institutions in enforcing the code of conduct and code of behavior of politicians and political parties.
One important thing to note is that the code of conduct and code of behavior of politicians and political parties should correspondingly, coherent and does not conflict with the legal rules in force in that State, of the CONSTITUTION, the election LAW, the party's Executive and legislative branches. Harmonization of legislation related to political parties, politicians, elections, governance in the Centre and in the regions is an inevitability.

The code of conduct and code of behavior of politicians and political parties need to be made and applied in good order for political parties and politicians behave and conduct that good anyway. It is necessary for the Court of Justice and ethics are ad hoc outside the party's institutions in order to apply to all political parties and politicians. This is all to build political legitimacy and public confidence toward political parties and politicians as well as build an established democratic system. Good political parties and politicians will make democracy in Indonesia is good also, and vice versa.

\section{BIBLIOGRAPHY}

Amal, Ichlasul, ed., Teori-Teori Mutakhir Partai Politik, (Yogyakarta: TWC, 1996).

Maor, Moshe, Political Parties \& Party Systems: Comparative Approaches \& the British Experience, (London and New York: Routledge, 1997).

Meny, Yves and Andrew Knapp. 1988. Government and Politics in Western Europe: Britain, France, Italy, Germany. Third Edition.Oxford University Press.

Michels, Robert. 1984. Partai Politik: Kecenderungan Oligarkis dalam Birokrasi. Jakarta: Penerbit Rajawali.

Monica and Jean Charlot, 'Les Groupes Politiques dan sleur Environement' in J. Lecaand M. Grawitz (eds.), Traite de Science Politique, iii (Paris: PUF, 1985. 
Rousseau, Jean, Jacques. 1762. The Social Contract Or Principles of Political Right. Virgi: Foederisæquas Dicamusleges.

Schattschneider.E.E. 1942.Party Government. New York: Holt. Rinehart and Winston.

Suleman, Zulfikri, "Mahkamah Etik Penyelenggara Negara di Negara Demokrasi," dalam Jurnal Etika \& Pemilu, edisi 1, Mei 2015: 14.

Yin, Robert, K. (2009).Case Study Research, Design and Methods.Fourth Edition. Thousand Oaks: Sage Publications. 